\title{
Bactericidal versus Bacteriostatic Antibiotic Therapy of Experimental Pneumococcal Meningitis in Rabbits
}

\author{
W. Michael Scheld, Division of Infectious Disease, Department of Internal \\ Medicine, University of Virginia School of Medicine, Charlottesville, \\ Virginia 22908 \\ Merle A. SANDe, Medical Service, San Francisco General Hospital Medical \\ Center and Department of Medicine, University of California at San \\ Francisco, California 94110
}

\begin{abstract}
A в S T R A C T A rabbit model of pneumococcal meningitis was used to examine the importance of bactericidal vs. bacteriostatic antimicrobial agents in the therapy of meningitis. 112 animals were infected with one of two strains of type III Streptococcus pneumoniae. Both strains were exquisitely sensitive to ampicillin, minimum inhibitory concentration (MIC)/ minimum bactericidal concentration $(\mathrm{MBC})<0.125$ $\mu \mathrm{g} / \mathrm{ml}$. The activity of chloramphenicol against the two strains varied: $\operatorname{strain}_{1}-\mathrm{MIC} 2 \mu \mathrm{g} / \mathrm{ml}$, MBC 16 $\mu \mathrm{g} / \mathrm{ml} ;$ strain $_{2}-\mathrm{MIC} 1 \mu \mathrm{g} / \mathrm{ml}$, MBC $2 \mu \mathrm{g} / \mathrm{ml}$. Animals were treated with either ampicillin or chloramphenicol in dosages that achieved a peak bactericidal effect in cerebrospinal fluid (CSF) for ampicillin against both strains. Two different dosages were used for chloramphenicol. The first dosage achieved a peak CSF concentration of $4.4 \pm 1.1 \mu \mathrm{g} / \mathrm{ml}$ that produced a bacteriostatic effect against strain $n_{1}$ and bactericidal effect against $\operatorname{strain}_{2}$. The second dosage achieved a bactericidal effect against both strains (mean peak CSF concentration $30.0 \mu \mathrm{g} / \mathrm{ml}$ ). All animals were treated intramuscularly three times a day for $5 \mathrm{~d}$. CSF was sampled daily and $3 \mathrm{~d}$ after discontinuation of therapy for quantitative bacterial cultures. Results demonstrate
\end{abstract}

Portions of this work were presented at the Annual Meeting of the American Federation for Clinical Research, Wash., D.C., May 1979, and was published in abstract form in 1979. Clin. Res. 27: 355a. (Abstr.)

Dr. Scheld is the recipient of the Clinical Investigator Award 1-K08-AI00517-01 from the National Institute of Allergy and Infectious Diseases.

Address all correspondence to Dr. W. M. Scheld, Division of Infectious Diseases, University of Virginia School of Medicine, Charlottesville, VA 22908.

Received for publication 28 June 1982 and in revised form 9 November 1982. that only antimicrobial therapy that achieved a bactericidal effect in CSF was associated with cure. Over $90 \%$ of animals treated with one of the bactericidal regimens (i.e., animals in which the bacterial counts in CSF dropped $>5 \log _{10}$ colony-forming units [cfu]/ $\mathrm{ml}$ after $48 \mathrm{~h}$ ) had sterile CSF after $5 \mathrm{~d}$ of treatment. On the other hand, the regimen that achieved bacteriostatic concentrations (CSF drug concentrations between the MIC and MBC) produced a drop of $2.4 \log _{10}$ $\mathrm{cfu} / \mathrm{ml}$ by $48 \mathrm{~h}$; however, none of the animals that survived had sterile CSF after $5 \mathrm{~d}$. These studies clearly demonstrate in a strictly controlled manner that maximally effective antimicrobial therapy of experimental pneumococcal meningitis depends on achieving a bactericidal effect in CSF.

\section{INTRODUCTION}

Despite the introduction of newer antibiotics (e.g., ampicillin or chloramphenicol), the mortality rate in pneumococcal meningitis has not improved since penicillin was introduced for therapy more than $30 \mathrm{yr}$ ago. In six large series of studies comprising 439 patients over the last three decades, recently reviewed (1), the mortality rate of pneumococcal meningitis ranged from 17 to $59 \%$ (mean of $28 \%$ ), identical to the overall case fatality rate for cases treated in the United States and reported to the Centers for Disease Control in 1978 (2). Although certain poor prognostic factors, especially coma (3), may indicate an irreversible process at admission in many cases, the choice and method of administration of antibiotics also is of critical importance.

Several lines of evidence indicate that bacterial meningitis represents an infection in an area of impaired host resistance. Bacterial concentrations within 
the cerebrospinal fluid $(\mathrm{CSF})^{1}$ reach enormous population densities within $72 \mathrm{~h}$ of the onset of the illness, e.g., $\geq 10^{7}$ colony-forming units $(\mathrm{cfu}) / \mathrm{ml}$ of $\mathrm{CSF}$ in many cases $(4,5)$. The polymorphonuclear leukocytes seem to contribute little defense in such cases. Surface phagocytosis, an important factor in promoting phagocytosis of unopsonized pneumococci within alveoli in pneumonia (6), is poor in the fluid medium of the CSF. Since specific antibody and functional complement components are absent from CSF early in the course of infection (7-10), efficient phagocytosis of the encapsulated pneumococci may not occur. Thus, bacterial multiplication continues unimpeded within the CSF before the leukocytes appear, despite the chemoattractiveness of purulent CSF $(11,12)$. Cases of pneumococcal meningitis with a turbid CSF due solely to bacteria (e.g., low leukocyte counts) are well recognized clinically, and generally are fatal. A high CSF bacterial concentration with a low leukocyte count before therapy is a poor prognostic sign in both experimental meningitis (13) and man $(4,5,14)$.

Thus, as in other infections where host defenses are impaired, like bacterial endocarditis or bacteremia in leukopenic patients $(15,16)$, one would expect that optimal therapy of bacterial meningitis would require achieving a bactericidal effect at the site of infection. Several experimental studies suggest that this is the case. CSF aminoglycoside levels greatly exceeding the minimum bactericidal concentration (MBC) were necessary for effective reduction in bacterial titers in vivo in experimental meningitis induced by gram-negative bacilli (17), where chloramphenicol, a static agent, was without effect (18). In another study, a bactericidal, but not a bacteriostatic, combination regimen was effective in reducing numbers of viable bacteria in experimental Escherichia coli meningitis (19). Comparable information for pneumococcal meningitis in either animals or man is not available, and the requirement for bactericidal therapy in any form of meningitis remains unproven.

Because it is impossible to study these principles in man, experimental models of infection must be utilized. This study was specifically designed to determine the importance of achieving a bactericidal effect vs. a bacteriostatic effect in CSF on the cure of experimental pneumococcal meningitis. We utilized two drugs (ampicillin and chloramphenicol), in different dosages, and two strains of pneumococci with different susceptibilities to approach this problem.

\footnotetext{
${ }^{1}$ Abbreviations used in this paper: $\mathrm{cfu}$, colony-forming units; CSF, cerebrospinal fluid; MBC, minimum bactericidal concentration; MIC, minimum inhibitory concentration.
}

\section{METHODS}

\section{In vitro studies}

The minimum inhibitory concentrations (MIC) and MBC of ampicillin and chloramphenicol were determined against seven recent CSF isolates of Streptococcus pneumoniae (three were type III). The organisms were incubated at $37^{\circ} \mathrm{C}$ in $10 \% \mathrm{CO}_{2}$ overnight $(18 \mathrm{~h})$ in brain heart infusion broth (BHIB, Difco Laboratories, Detroit, MI) supplemented with $5 \%$ defibrinated sheep blood. After centrifugation $(3,000 \mathrm{~g}$ for $15 \mathrm{~min}$, twice) and double washing in $0.9 \% \mathrm{NaCl}$, the bacteria were suspended in Mueller-Hinton broth with 5\% defibrinated sheep blood at a final concentration of $5 \times 10^{5}$ $\mathrm{cfu}$ in $0.2-\mathrm{ml}$ wells. A broth microdilution technique (Cooke Engineering Co., Alexandria, VA) was used. The MIC was defined as the lowest concentration of drug preventing visible turbidity after $24 \mathrm{~h}$ at $37^{\circ} \mathrm{C}$ in $10 \% \mathrm{CO}_{2}$. All clear wells were then subcultured $(0.01 \mathrm{ml})$ on drug-free blood agar for determination of the MBC, defined as the lowest dilution of antibiotic that achieved complete sterility of the wells after a further $24-\mathrm{h}$ incubation at $37^{\circ} \mathrm{C}$ in $10 \% \mathrm{CO}_{2}$.

Quantitative bactericidal assays ("time-kill curves") were performed for three representative isolates of $S$. pneumoniae. The organisms were grown overnight (as above), centrifuged $(3,000 \mathrm{~g}$ for $15 \mathrm{~min}$, twice) washed, and added to Mueller-Hinton broth containing 5\% defibrinated sheep blood in 25-ml cotton-stoppered flasks at a final inoculum of $\simeq 10^{5.5} \mathrm{cfu} / \mathrm{ml}$. The flasks containing either no drug (controls), ampicillin $(2.5 \mu \mathrm{g} / \mathrm{ml})$, or chloramphenicol $(10 \mu \mathrm{g} /$ $\mathrm{ml}$ ), were incubated at $37^{\circ} \mathrm{C}$ in $10 \% \mathrm{CO}_{2}$ on a rotary shaker providing constant, gentle agitation. Samples $(0.5 \mathrm{ml})$ were removed at $0,4,12$ and $24 \mathrm{~h}$, serially diluted in $0.9 \% \mathrm{NaCl}$, and quantitatively titered on trypticase soy agar (TSA, BBL Microbiology Systems, Beeton, Dickinson \& Co., Cockeysville, MD) pour plates containing $5 \%$ defibrinated sheep blood. Duplicate experiments were performed on each strain with essentially identical results.

\section{In vivo studies}

Rabbit model. New Zealand White rabbits $(2-3 \mathrm{~kg})$ were prepared, with minor modifications, as previously described $(20,21)$. A dental acrylic helmet was attached to the animal's skull to facilitate rigid immobilization within a stereotaxic frame. A Quincke spinal needle, 25 gauge by 3.5 in $(\sim 9$ $\mathrm{cm}$ ), was introduced percutaneously and atraumatically into the cisterna magna by a geared electrode introducer. These needles were used for both initial bacterial inoculation and for CSF sampling during the treatment course.

Preparation of inocula. Two strains of S. pneumoniae, type III, were grown overnight at $37^{\circ} \mathrm{C}$ in $10 \% \mathrm{CO}_{2}$ in BHIB plus $5 \%$ defibrinated sheep blood and centrifuged $(400 \mathrm{~g}$ for $5 \mathrm{~min})$ to remove erythrocytes. The organisms were then recentrifuged $(3,000 \mathrm{~g}$ for $15 \mathrm{~min})$ and washed in $0.9 \% \mathrm{NaCl}$ twice before suspension in $2 \mathrm{ml} 0.9 \% \mathrm{NaCl}$ at a final concentration of $\simeq 10^{7.5} \mathrm{cfu} / \mathrm{ml}$.

Production of meningitis. After withdrawal of clear CSF $(0.3 \mathrm{ml})$ the bacterial inocula (in $0.2 \mathrm{ml}$ ) were slowly injected into the cisterna magna at a final concentration of $\simeq 2 \times 10^{7}$ $\mathrm{cfu} / 0.2 \mathrm{ml}$. The postinoculation interval before the initiation of therapy was 16-18 h. All animals had meningitis as manifest by fever $\left(>40^{\circ} \mathrm{C}\right.$ ), neurologic signs (principally lethargy and/or opisthotonus), a CSF pleocytosis $\left(5 \times 10^{2}\right.$ to $>2.5$ $\times 10^{3}$ leukocytes $/ \mathrm{mm}^{3}, \geq 95 \%$ polymorphonuclear leuko- 
cytes) and CSF bacterial concentrations of $\log _{10} 4.0$ to $>8.0$ $\mathrm{cfu} / \mathrm{ml}$. All untreated control animals died within $96 \mathrm{~h}$ of infection.

\section{Experimental design}

Treatment of 112 animals was begun $16 \mathrm{~h}$ after inoculation with one of three antibiotic dosages: ampicillin $(250 \mathrm{mg})$, chloramphenicol ( 375 or $1,000 \mathrm{mg}$ ). All drugs were given intramuscularly three times daily, and the formulations used were sterile ampicillin sodium (Polycillin-N, Bristol-Myers Products, New York) and sterile chloramphenicol sodium succinate (Chloromycetin, Parke-Davis, division of WarnerLambert Company, Morris Plains, NJ). Daily samples of serum $(3 \mathrm{ml}$ venous blood) and CSF $(0.25 \mathrm{ml})$ were obtained during the 5-d treatment period. After $5 \mathrm{~d}$ of therapy all antibiotics were stopped, and the CSF was sampled $3 \mathrm{~d}$ later ( $8 \mathrm{~d}$ after inoculation) to determine the incidence of relapses, if any. In addition, serum $(1.0 \mathrm{ml})$ and $\operatorname{CSF}(0.15 \mathrm{ml})$ samples were obtained frequently after the morning dose on days 2 and 3 to define drug pharmacokinetics and delivery into the CSF. The times of sampling (in hours after the dose) were $0.5,1,1.5,2,3,4,6$, and 8 .

Two strains of $S$. pneumoniae type III were used in these studies to assess the influence of CSF bactericidal activity on outcome. The MBC of chloramphenicol for the first strain (strain ${ }_{1}$ ) was $16 \mu \mathrm{g} / \mathrm{ml}$, which was above the mean CSF concentration of $4 \mu \mathrm{g} / \mathrm{ml}$ attained on "low"-dose chloramphenicol therapy ( $375 \mathrm{mg}$ t.i.d.) but below the CSF chloramphenicol concentration of $30 \mu \mathrm{g} / \mathrm{ml}$ achieved when the "high"-dose chloramphenicol (1,000 mg t.i.d.) was used. The second strain ( strain $_{2}$ ) had a MBC of $2 \mu \mathrm{g} / \mathrm{ml}$, which was below the mean CSF chloramphenicol concentrations achieved with either regimen.

The influence of the antibiotic regimen on rate of decline in CSF bacterial titers over the first 24 and $48 \mathrm{~h}$ of treatment, and the cure and relapse rates, were determined in all groups. All 12 untreated animals died of infection within $\mathbf{7 2}$ $h$ after inoculation. "Cure" was defined as disease-free survival with sterile CSF $8 \mathrm{~d}$ after inoculation. A "relapse" was defined as a positive CSF-culture and rise in pneumococcal titers between 5 and $8 \mathrm{~d}$ after inoculation. To obviate any adverse influence of anesthesia or cisternal puncture on the results, animals that died within $30 \mathrm{~min}$ of these procedures were excluded from computation of the results.

Antibiotic assays. Antibiotic concentrations were determined by agar-well diffusion techniques. Bacillus subtilis spore suspension $(0.9 \mathrm{ml}$, Difco Laboratories) was added to $1,000 \mathrm{ml}$ antibiotic medium No 11 (Difco Laboratories) for determination of ampicillin levels. The initial chloramphenicol assays used a 2.5-ml suspension of Sarcina lutea (ATCC 9341) incorporated into antibiotic medium No 1 (Difco Laboratories). This suspension gave a transmission of $21 \%$ at 580 $\mathrm{nm}$. Most (>90\%) chloramphenicol bioassays, however, were performed against a marine bacterium, Beneckea natrigens in $1.5 \%$ salt agar, because this technique is simpler, more rapid, highly reproducible, and requires smaller volumes of sample (22). The lower limit of detectability of this bioassay was only $\simeq 2 \mu \mathrm{g} / \mathrm{ml}$; therefore, all samples with no zone of inhibition were repeated with a highly sensitive enzymatic assay (23) in Dr. Paul Lietman's laboratory, Johns Hopkins University, School of Medicine, Baltimore, MD. In addition, a minimum of four samples were chosen at random from each animal and repeated with the enzymatic assay. These results were read blind; there was excellent agreement $( \pm 10 \%)$ between the two methods. Both the bioassay and enzymatic method detected only active free chloramphenicol and were not affected by unhydrolyzed succinate ester in serum or CSF. All specimens and standards were analyzed in triplicate. Wells $(4.7 \mathrm{~mm}$ for ampicillin, $6.6 \mathrm{~mm}$ for chloramphenicol) were cut into the agar and filled with 0.03-0.07 $\mathrm{ml}$ of specimen. All serum standards used pooled rabbit serum; CSF standards were performed in $0.9 \% \mathrm{NaCl}$ after zones in all systems were found to be equivalent after dilution in $0.9 \% \mathrm{NaCl}$, normal pooled rabbit $\mathrm{CSF}$, or purulent rabbit CSF.

Analysis of data. Student's two-tailed $t$ test was used on unpaired data to detect any differences between regimens in the rate of decline of CSF bacterial concentrations during therapy. Differences in the degree of sterilization at suitable time intervals in the treatment course (number sterile CSF observed/total number treated), cure rate, and relapse rate were sought between groups by chi square or Fisher's exact test analysis.

\section{RESULTS}

In vitro. The $\mathrm{MIC}$ and $\mathrm{MBC}$ of ampicillin against the seven strains of pneumococci were very low; all were $\leq 0.25 \mu \mathrm{g} / \mathrm{ml}$. The MBC for the two isolates selected for in vivo study were both $0.125 \mu \mathrm{g} / \mathrm{ml}$ for ampicillin. Although chloramphenicol MIC ranged from 0.5 to $2.0 \mu \mathrm{g} / \mathrm{ml}$ for these seven isolates, the MBC were generally higher ( 2 to $\geq 64 \mu \mathrm{g} / \mathrm{ml}$ ). Thus, chloramphenicol $\mathrm{MBC}$ for the two strains studied in vivo were as follows: $\operatorname{strain}_{1}=16 \mu \mathrm{g} / \mathrm{ml} ; \operatorname{strain}_{2}=2$ $\mu \mathrm{g} / \mathrm{ml}$.

In the dynamic bactericidal studies (Fig. 1), ampicillin sterilized (e.g., $<10^{1} \mathrm{cfu} / \mathrm{ml}$ due to sensitivity of the assay) the broth culture of both test strains of $S$. pneumoniae within $12 \mathrm{~h}$, while control cultures increased from $\sim 10^{5} \mathrm{cfu} / \mathrm{ml}$ to $\simeq 10^{8} \mathrm{cfu} / \mathrm{ml}$. The ampicillin concentration used $(2.5 \mu \mathrm{g} / \mathrm{ml})$ was similar to concentrations achievable in infected CSF and 20 times higher than the MBC. In contrast, chloramphenicol, at the concentration tested $(10 \mu \mathrm{g} / \mathrm{ml})$ was rapidly bactericidal for $\operatorname{strain}_{2}$ only (Fig. 1b). This concentration exceeded the MBC by fivefold. Chloramphenicol (at $10 \mu \mathrm{g} / \mathrm{ml}$ ) produced a bacteriostatic effect against strain $_{1}$. The concentration used was approximately one-half the MBC $(16 \mu \mathrm{g} / \mathrm{ml})$ of the organism (Fig. 1a).

In vivo. Multiple serum and CSF samples were obtained for antibiotic concentrations from at least 20 animals following each dosage studied. All samples were obtained on either day 2 or 3 of infection. The mean $\pm S D$ serum and CSF concentrations of ampicillin and chloramphenicol during intermittent intramuscular injection therapy are shown in Figs. 2 and 3. The highest peak serum levels were $62 \mu \mathrm{g} / \mathrm{ml}$ and were observed at the first interval sampled (30 min after dosing) for ampicillin. The concentration rapidly declined, and all serum ampicillin concentrations were $\leq 0.2 \mu \mathrm{g} / \mathrm{ml}$ by $6 \mathrm{~h}$ after injection. The mean peak CSF 



FIgURE 1 (a) Mean \pm SD $\log _{10} \mathrm{cfu} / \mathrm{ml}$ S. pneumoniae (strain ${ }_{1}$ ) during incubation in vitro with no drug-controls $(-0)$, ampicillin $(2.5 \mu \mathrm{g} / \mathrm{ml} ; \mathrm{O}-\mathrm{O})$, and chloramphenicol (10 $\mu \mathrm{g} /$ $\mathrm{ml}$; - - - ). (b) Mean \pm SD $\log _{10} \mathrm{cfu} / \mathrm{ml} \mathrm{S}$. pneumoniae (strain $\mathrm{n}_{2}$ ) during incubation in vitro with no drug-controls $(-)$, ampicillin $(2.5 \mu \mathrm{g} / \mathrm{ml} ; \mathrm{O}-\mathrm{O})$, and chloramphenicol $(10 \mu \mathrm{g} / \mathrm{ml} ; 0--0)$.

ampicillin concentration also occurred at $30 \mathrm{~min}$ after injection and was $10-15 \%$ of the concurrent serum concentration in each animal.

The serum and CSF chloramphenicol concentrations were dependent on dose (Fig. 3). The initial dosage used (375 mg i.m.) was designed to produce serum levels equivalent to those found in man on standard parenteral regimens. This goal was achieved with mean peak serum chloramphenicol levels $1 \mathrm{~h}$ after injection of $24 \mu \mathrm{g} / \mathrm{ml}$. At this time the mean \pm SD CSF chloramphenicol level was $4.4 \pm 1.1 \mu \mathrm{g} / \mathrm{ml}, \sim 20 \%$ of the simultaneous serum concentrations. When the dose was raised (to $1,000 \mathrm{mg}$ i.m.) to achieve CSF chloramphenicol levels in excess of the MBC of both test



FIGURE 2 Mean $\pm S D$ ampicillin concentration (micrograms per milliliter) in serum $(\mathrm{O}-\mathrm{O})$ and cerebrospinal fluid $(---\bullet)$ vs. time after injection (hours) of $250 \mathrm{mg}$ i.m. in rabbits. 


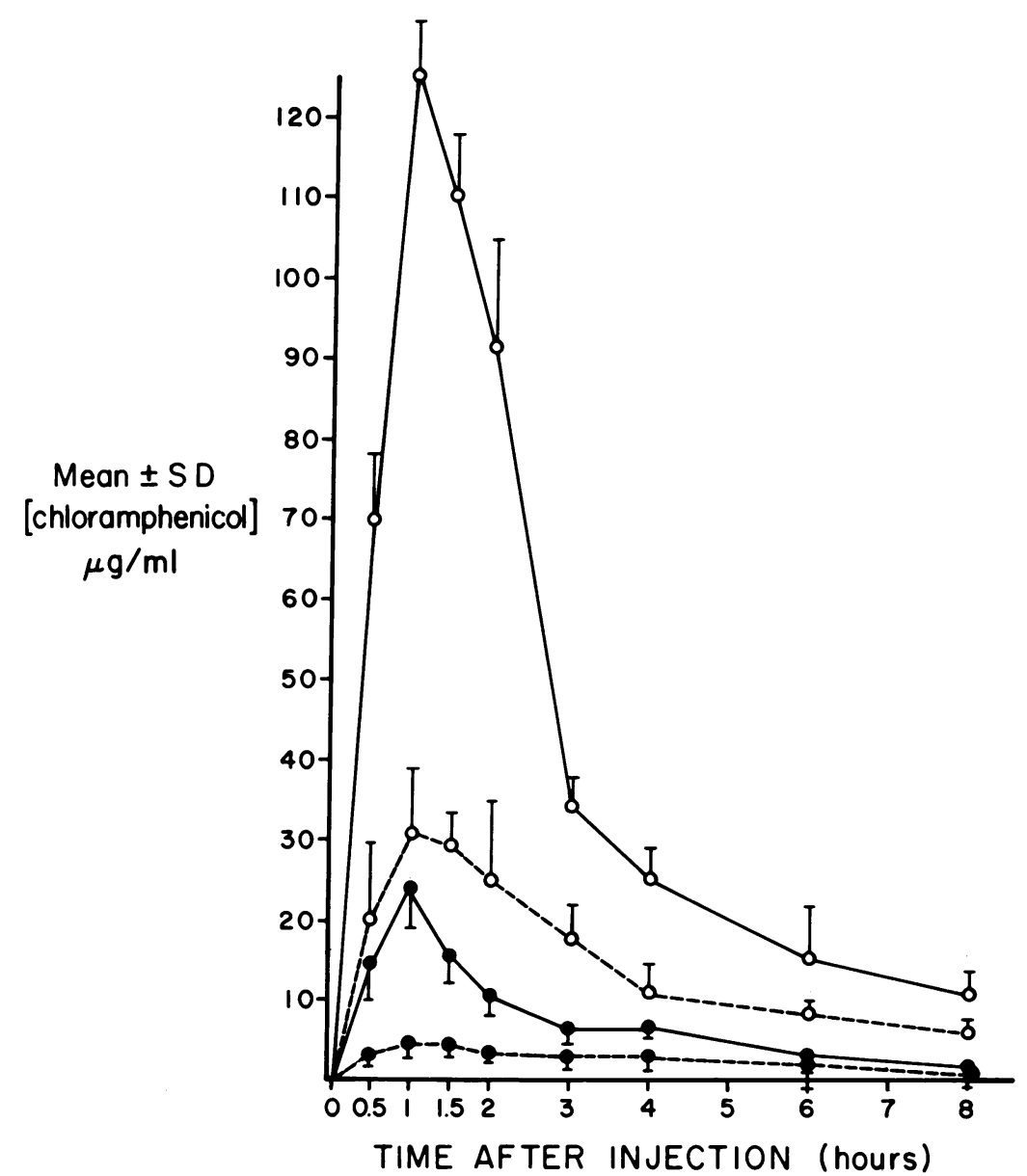

FigURE 3 Mean \pm SD chloramphenicol concentration (micrograms per milliliter) in serum $(\mathrm{O}-\mathrm{O})$ and $\mathrm{CSF}(\mathrm{O}$ - - - O) vs. time after injection (hours) of $1,000 \mathrm{mg}$ i.m.; and mean \pm SD chloramphenicol concentration (micrograms per milliliter) in serum $(\bullet-\bullet)$ and CSF (- - - ) vs. time after injection (hours) of $375 \mathrm{mg}$ i.m. in rabbits.

strains, the mean peak levels were $126 \mu \mathrm{g} / \mathrm{ml}$ in the serum and $30 \mu \mathrm{g} / \mathrm{ml}$ in the CSF. The $\mathrm{T}_{1 / 2}$ in CSF was longer for chloramphenicol than for ampicillin, and concentrations were detectable $(\geq 1 \mu \mathrm{g} / \mathrm{ml})$ in all the CSF samples $8 \mathrm{~h}$ after injection.

The mean peak CSF ampicillin concentrations exceeded the MBC $(0.125 \mu \mathrm{g} / \mathrm{ml})$ for both strains of pneumococci used in these experiments in all animals. In contrast, only the high-dose chloramphenicol group ( $1,000 \mathrm{mg} /$ injection) developed mean peak CSF chloramphenicol concentrations $(\simeq 30 \mu \mathrm{g} / \mathrm{ml})$ in excess of the MBC $(16 \mu \mathrm{g} / \mathrm{ml})$ for $\operatorname{strain}_{1}$, whereas CSF levels $(4.4 \mu \mathrm{g} / \mathrm{ml})$ in the low-dose group were below this MBC. Both chloramphenicol regimens, however, produced peak CSF levels of drug above the MBC $(2 \mu \mathrm{g} /$ ml) for $\operatorname{strain}_{2}$.

The results of therapy with the 5-d regimens used in experimental pneumococcal meningitis are shown

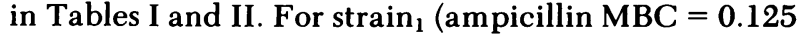

$\mu \mathrm{g} / \mathrm{ml}$; chloramphenicol MBC $=16 \mu \mathrm{g} / \mathrm{ml}$ ), the lowdose chloramphenicol regimen was less effective than ampicillin in reducing CSF pneumococcal concentrations after $24 \mathrm{~h}$ (e.g., three doses) of treatment $(P<0.001)$ (Fig. 4a, Table I). The high-dose chloramphenicol group (with mean CSF drug concentrations two times the $\mathrm{MBC}$ ) reduced the mean CSF pneumococcal concentrations $\sim 5.5 \mathrm{logs}$ after $24 \mathrm{~h}$ and was equivalent to ampicillin alone. After $5 \mathrm{~d}$ of therapy, none of the surviving animals treated with 375 $\mathrm{mg}$ of chloramphenicol t.i.d. had a sterile CSF compared with $92-100 \%$ in the other two groups ( $P$ $<0.001$ ) (Table I). When lower doses of chloramphenicol were used (125 or $250 \mathrm{mg}$ i.m. t.i.d.; $n=5$ ), all animals died of infection within $72 \mathrm{~h}$ (data not shown). The mean peak CSF chloramphenicol concentration was $<2 \mu \mathrm{g} / \mathrm{ml}$ and below the $\mathrm{MBC}$ of the organism.

When $\operatorname{strain}_{2} \quad(a m p i c i l l i n ~ M B C=0.125 \mu \mathrm{g} / \mathrm{ml}$; 
TABLE I

Results of Therapy in Experimental Pneumococcal Meningitis

\begin{tabular}{llcccc}
\hline Inoculum & \multicolumn{1}{c}{ Drug } & Dose & $\begin{array}{c}\Delta \log _{10} \text { cfu/ml CSF } \\
\text { after } 24 \mathrm{~h}\end{array}$ & $\begin{array}{c}\Delta \log _{10} \text { cfu/ml CSF } \\
\text { after } 48 \mathrm{~h}\end{array}$ & $\begin{array}{c}\text { Survival with } \\
\text { sterile CSF after 5 d }\end{array}$ \\
\hline \multirow{4}{*}{ Strain $_{1}$} & mg i.m. t.i.d. & \multicolumn{2}{c}{ Mean $\pm S D$} & $\%$ \\
& Ampicillin & 250 & $-5.3 \pm 1.4(22)$ & $-5.5 \pm 1.1(19)$ & $92(18)$ \\
& Chloramphenicol & 375 & $-1.5 \pm 1.3(14)$ & $-2.4 \pm 1.7(12)$ & $0(9)$ \\
\multirow{2}{*}{ Strain $_{2}$} & Chloramphenicol & 1,000 & $-5.5 \pm 1.0(11)$ & $-5.3 \pm 1.5(9)$ & $90(10)$ \\
& Ampicillin & 250 & $-5.9 \pm 0.9(16)$ & $-5.6 \pm 1.2(14)$ & $100(9)$ \\
& Chloramphenicol & 375 & $-3.5 \pm 0.5(12)$ & $-4.6 \pm 1.4(11)$ & $100(8)$ \\
\hline
\end{tabular}

The number in parentheses represents the number of animals used in each computation.

chloramphenicol $\mathrm{MBC}=2 \mu \mathrm{g} / \mathrm{ml}$ ) was used as the infecting organism, the results were different (Fig. $4 \mathrm{~b}$, Table I). When chloramphenicol was administered at the lower dose, a more pronounced bactericidal effect was produced; pneumococcal titers decreased 3.5 logs in $24 \mathrm{~h}$ and 4.6 logs in $48 \mathrm{~h}$ and all surviving animals had sterile CSF after $5 \mathrm{~d}$ of treatment. The concentration of chloramphenicol achieved within the CSF with these dosages exceeded the MBC of the test strain $\left(\operatorname{strain}_{2}\right)$ by two- to threefold. On the other hand, the CSF concentration of ampicillin achieved with this dosage exceeded the MBC of the test strain by 20 to 30 times, and the decline in CSF titer in $24 \mathrm{~h}$ was 5.9 and 5.6 logs after $48 \mathrm{~h}(P<0.05$ when compared with chloramphenicol).

These differences between treatment groups were largely consistent with cure and relapse rates (Table II). Cure, defined as disease-free survival to day 8 (3 $\mathrm{d}$ after treatment was terminated) with a documented sterile CSF, was achieved in only 3 of 18 animals infected with the strain that was tolerant to chloramphenicol $\left(\operatorname{strain}_{1}\right)$ and treated with the low-dose chloramphenicol regimen compared with 17 of 22 receiving ampicillin alone $(P=0.022)$. The regimen of highdose chloramphenicol produced cure rates not significantly different from ampicillin alone. $70-80 \%$ of an-

TABle II

Results of Therapy in Experimental Pneumococcal Meningitis

\begin{tabular}{llrrrr}
\hline \multirow{2}{*}{ Inoculum } & \multicolumn{1}{c}{ Drug } & Dose & $\begin{array}{c}\text { Cured/ } \\
\text { Total }\end{array}$ & $\begin{array}{c}\text { Cure } \\
\text { rate }\end{array}$ & $\begin{array}{c}\text { Relapse } \\
\text { rate }\end{array}$ \\
\hline \multirow{4}{*}{ Strain $_{1}$} & & Am i.m.t.i.d. & & & $\%$ \\
& & 250 & $17 / 22$ & 77 & 0 \\
& Chloramphenicol & 375 & $3 / 18$ & 17 & 67 \\
& Chloramphenicol & 1,000 & $7 / 11$ & 64 & 12.5 \\
Strain $_{2}$ & Ampicillin & 250 & $8 / 10$ & 80 & 11 \\
& Chloramphenicol & 375 & $7 / 10$ & 70 & 12.5 \\
\hline
\end{tabular}

416 W. M. Scheld and M. A. Sande imals infected with the highly chloramphenicol-sensitive strain of S. pneumoniae $\left(\right.$ strain $_{2}$ ) were cured with ampicillin or low-dose chloramphenicol and there were no differences between treatment groups.

Relapses (defined as a rise in CSF pneumococcal concentration between the end of therapy, day 5 and day 8) were rarely observed except in the low-dose chloramphenicol group in animals inoculated with strain $_{1}$. In this group, six of nine surviving animals on day 5 demonstrated a relapse vs. one of eight in the high-dose chloramphenicol group $(P<0.05)$. No relapses were observed in the animals infected with strain $_{1}$ and treated with ampicillin (Table II) although $5 / 22$ died during treatment. Only 2 of 17 animals relapsed when inoculated with $\operatorname{strain}_{2}$, and all treatment regimens were equivalent when this parameter was examined $(P>0.5)$.

\section{DISCUSSION}

This study examines the critical importance of bactericidal vs. bacteriostatic antibiotic therapy of experimental bacterial meningitis. Two antimicrobial agents, ampicillin and chloramphenicol, were used as probes to explore this question. Under the condition of the present study, one of these agents, ampicillin, always achieved bactericidal activity within the infected CSF in vivo in experimental pneumococcal meningitis, whereas the other agent, chloramphenicol, achieved bactericidal activity in only one model of infection. Dosages were chosen and two pneumococcal strains were selected to test the hypothesis that bactericidal activity at the site of infection (e.g., CSF) was necessary for a successful outcome. The results strongly support the conclusion that when CSF antibiotic levels exceeded the MBC for the test strain, the results of therapy were significantly better by all parameters than the results achieved with regimens that did not attain CSF antibiotic concentrations above this level. 

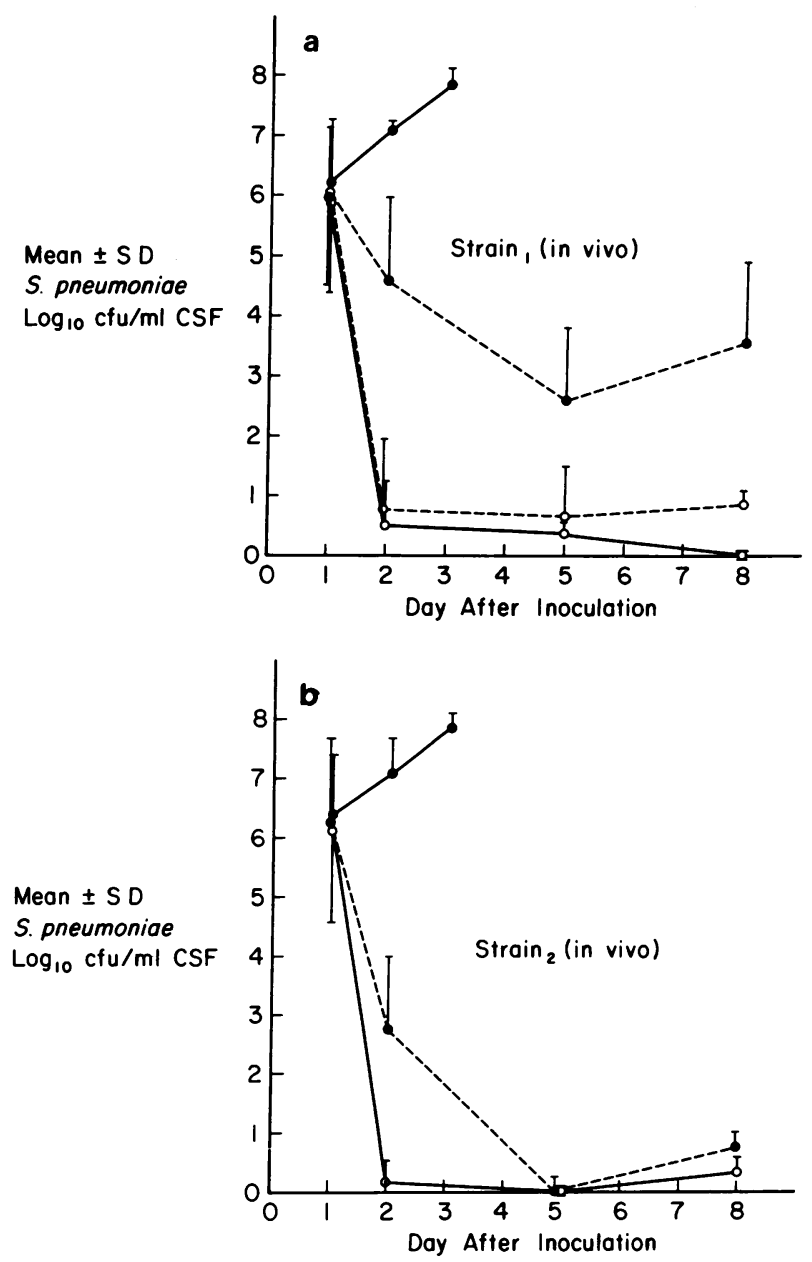

Figure 4 (a) Mean \pm SD S. pneumoniae $\log _{10} \mathrm{cfu} / \mathrm{ml}$ CSF vs. day after inoculation in rabbits with experimental meningitis treated on days 1-5. Drugs (dose in milligrams, intramuscular, t.i.d.): none (controls; - - ); ampicillin (250; $\mathrm{O}-\mathrm{O})$; chloramphenicol (375; $---\bullet)$; and chloramphenicol $\left(1,000 ; O_{--}-0\right)$. Data are shown for animals infected with strain ${ }_{1}$. (b) Mean \pm SD $S$. pneumoniae $\log _{10} \mathrm{cfu} / \mathrm{ml} \mathrm{CSF}$ vs. day after inoculation, in rabbits with experimental meningitis treated on days 1-5. Drugs (dose in milligrams, intramuscular, t.i.d.): none (controls; - ); ampicillin (250; O-O); and chloramphenicol $(375 ;---0)$. Data are shown for animals infected with strain $_{2}$.

The need for bactericidal antibiotics for optimal therapy of bacterial meningitis is suggested by several lines of evidence: $(a)$ the disease represents an infection in an area of impaired host resistance $(7-9,13,24)$, and may, like bacterial endocarditis and bacteremia in the neutropenic host $(15,16)$, require bactericidal antibiotics for cure; and (b) most studies of experimental meningitis in animals suggest that CSF antibiotic concentrations must exceed the MBC of the test strain by severalfold to achieve rapid bacterial killing in vivo (17-19, 25-28).

Bacterial concentrations in CSF achieve huge population densities early in the disease course $(4,5)$. The densities (often $\geq 10^{7} \mathrm{cfu} / \mathrm{ml} \mathrm{CSF}$ ) are similar to those noted within cardiac vegetations in experimental animals and man with endocarditis $(29,30)$, a disease that requires bactericidal antibiotic therapy for cure. The CSF pneumococcal concentrations in the present experiments, before therapy, were in the range of $\log _{10}$ $4.0->8.0 \mathrm{cfu} / \mathrm{ml}$, similar to previously reported studies with experimental meningitis (27). In addition, concentrations regularly exceeded $10^{8} \mathrm{cfu} / \mathrm{ml} \mathrm{CSF}$ at the time of death in untreated animals, as noted in other studies $(12,27,28,31-34)$. These bacterial concentrations likely reflect inefficient host defense mechanisms at the site of infection. Leukocyte phagocytosis of unopsonized encapsulated organisms such as pneumococci is ineffective in the fluid medium of the CSF (6), but some resistance to infection must occur since the disease is more rapidly fatal in animals when CSF leukocyte concentrations are low $(13,35)$. Despite the detection of immunoglobulins in the CSF of patients with meningitis or encephalitis $(7,36,37)$, the functional activity of these components, in concert with complement, is very poor at the site of infection. $\mathrm{Pu}$ rulent CSF appears to lack significant bactericidal or opsonic activity $(7,8,10)$. Complement deficiencies predispose to recurrent bouts of meningitis $(38,39)$, and complement components are essential for the control of experimental pneumococcal infections in noncentral nervous system locales as well $(40,41)$. These relative deficiencies permit the extracellular pneumococci to continue multiplying within the CSF and strongly suggest the need for bactericidal antibiotics for cure. Two other host defense mechanisms are also potentially important. Bacteria grow slowly in CSF when compared with broth $(42)^{2}$, which may interfere with the action of certain antibiotics, such as the beta lactams, maximally effective during rapid bacterial growth. In addition, the normal clearance mechanism of the CSF is operative early during experimental meningitis (43), but resistance to CSF outflow increases during experimental meningitis in rabbits (44) and may seriously impair the removal of bacteria or toxic products from the subarachnoid space. This suggests that, early, rapid bactericidal activity within the CSF may be desirable in minimizing further damage to the central nervous system.

The above deficiencies in local host defense suggest that bactericidal drugs, e.g., CSF antibiotic concen-

\footnotetext{
${ }^{2}$ Sande, M. A., B. Hengstler, O. Zak, and W. M. Scheld. Unpublished observations.
}

Bactericidal Antibiotics in Meningitis 
trations that exceed the MBC of the infecting pathogen, are necessary for optimal bacterial killing in vivo in this disease, analogous to bacterial endocarditis and infection in the neutropenic host. Several studies from our laboratory and elsewhere have shown, in shortterm experiments using 8-9 $\mathrm{h}$ of antibiotic infusion, that this is indeed the case $(17-19,21,25-27,33)$. In general, rapid bacterial killing in vivo required a CSF drug concentration of a beta lactam of 10 to 20 times the MBC of the test strain $(17-19,27-30,45)$. The same pattern was noted with numerous organisms, all important meningeal pathogens, including pneumococci, Haemophilus influenzae, E. coli, Klebsiella pneumoniae, Proteus mirabilis, Listeria monocytogenes, and group B streptococci (17-19, 21, 25, 27, 33, 46). When the bactericidal activity of purulent CSF from infected treated rabbits was measured in vitro, the results correlated well with the above conclusions since titers of $\geq 1: 16$ were necessary for a rapid bactericidal effect in vivo $(25,26)$. These studies were of short duration; the experiments in this paper are confirmatory and extend these observations to long term (5 d) therapy and ultimate outcome (e.g., cure).

Our studies in rabbits, thus, provided the logical explanation for the dramatic differences in cure rates of pneumococcal meningitis reported by Lepper and Dowling (47) in 1951. They found a $79 \%$ cure rate in patients receiving penicillin $G$ alone (a bactericidal drug) but only a $30 \%$ cure rate in patients receiving penicillin plus chlortetracycline (a drug that antagonized the bactericidal action of penicillin resulting in a static effect). A recent report by Cherubin et al. (48) also suggests that patients who received chloramphenicol for meningitis caused by gram-negative bacilli had a higher failure rate than those treated with aminoglycosides alone (49). Chloramphenicol is a static drug against most gram-negative bacilli and, when used in combination with aminoglycosides, may reduce or eliminate the bactericidal activity of the latter drug (18).

Thus, these carefully controlled studies demonstrate the principle that optimal therapy of experimental bacterial meningitis in vivo requires the usage of bactericidal, not bacteriostatic antibiotics. Although we have not performed laborious 5-d treatment courses in other types of experimental bacterial meningitis, we believe the results with pneumococcal meningitis may also be applicable to other infectious etiologies. The evidence of this study suggests that bacterial meningitis, like endocarditis or septicemia in a neutropenic host, demands bactericidal antibiotics for optimal therapy. The few clinical studies reported suggest this concept. Certainly, antibiotics alone will not always determine the clinical course, but this principle appears valid and should be a rational goal when examining new antimicrobial agents for treatment of bacterial meningitis (49).

\section{ACKNOWLEDGMENTS}

The authors gratefully acknowledge the assistance of Dr. Paul Lietman in performance of the chloramphenicol enzymatic assays and would like to thank Diana M. Moscicki and Joyce Henderson for their assistance in the preparation of the manuscript.

\section{REFERENCES}

1. Hodges, R. G., and R. L. Perkins. 1975. Acute bacterial meningitis: an analysis of factors influencing prognosis. Am. J. Med. Sci. 270: 427-440.

2. Center for Disease Control. 1979. Bacterial meningitis and meningococcemia-United States, 1978. Morbid. Mortal. Weekly Report 28: 277-279.

3. Baird, D. R., H. C. Whittle, and B. M. Greenwood. 1976. Mortality from pneumococcal meningitis. Lancet. II: 1344-1346.

4. Feldman, W. E. 1976. Concentrations of bacteria in cerebrospinal fluid of patients with bacterial meningitis. J. Pediatr. 88: 549-552.

5. Feldman, W. E. 1977. Relation of concentrations of bacteria and bacterial antigen in cerebrospinal fluid to prognosis in patients with bacterial meningitis. $N$. Engl. J. Med. 296: 433-435.

6. Wood, W. B., M. R. Smith, and B. Watson. 1946. Studies on the mechanism of recovery in pneumococcal pneumonia IV. The mechanism of phagocytosis in the absence of antibody. J. Exp. Med. 84: 387-401.

7. Whittle, H. C., and B. M. Greenwood. 1977. Cerebrospinal fluid immunoglobulins and complement in meningococcal meningitis. J. Clin. Pathol. 30: 720-722.

8. Simberkoff, M. S., N. H. Moldover, and J. J. Rahal, Jr. 1980. Absence of detectable bactericidal and opsonic activities in normal and infected human cerebrospinal fluids. A regional host defense deficiency. J. Lab. Clin. Med. 95: 362-372.

9. Bernhardt, L. L., M. S. Simberkoff, and J. J. Rahal, Jr. 1981. Deficient cerebrospinal fluid opsonization in experimental Escherichia coli meningitis. Infect. Immun. 32: 411-413.

10. Scheld, W. M., and J. P. Brodeur. 1981. Complementmediated opsonic and bactericidal activity in experimental bacterial meningitis. Intersci. Conf. Antimicrob. Agents Chemother. Proc. 21: Abstr. No. 450.

11. Greenwood, B. M. 1978. Chemotactic activity of cerebrospinal fluid in pyogenic meningitis. J. Clin. Pathol. 31: 213-216.

12. Wyler, D. J., S. I. Wasserman, and A. W. Karchmer. 1979. Substances which modulate leukocyte migration are present in CSF during meningitis. Ann. Neurol. 5: 322-326.

13. Giampaolo, C., W. M. Scheld, J. Boyd, J. Savory, M. Sande, and M. Wills. 1981. Leukocyte and bacterial interrelationships in experimental meningitis. Ann. Neurol. 9: 328-333.

14. Rischbieth, R. H. 1960. Pneumococcal meningitis: a killing disease. Med. J. Aust. 1: 578-581.

15. Sande, M. A., and W. M. Scheld. 1980. Combination antibiotic therapy of bacterial endocarditis. Ann. Intern. Med. 92: 390-395.

16. Klastersky, J., R. Cappel, and D. Daneau. 1972. Clinical 
significance of in vitro synergism between antibiotics in gram-negative infections. Antimicrob. Agents Chemother. 2: 470-475.

17. Strausbaugh, L. J., C. D. Mandaleris, and M. A. Sande. 1977. Comparison of four aminoglycoside antibiotics in the therapy of experimental $E$. coli meningitis. J. Lab. Clin. Med. 89: 692-701.

18. Strausbaugh, L. J., and M. A. Sande. 1978. Factors influencing the therapy of experimental Proteus mirabilis meningitis in rabbits. J. Infect. Dis. 137: 251-260.

19. Scheld, W. M., F. N. Fink, D. D. Fletcher, and M. A. Sande. 1979. Mecillinam-ampicillin synergism in experimental Enterobacteriaceae meningitis. Antimicrob. Agents Chemother. 16: 271-276.

20. Dacey, R. G. Jr., and M. A. Sande. 1974. Effect of probenecid on cerebrospinal fluid concentrations of penicillin and cephalosporin derivatives. Antimicrob. Agents Chemother. 6: 437-441.

21. Scheld, W. M., D. D. Fletcher, F. N. Fink, and M. A. Sande. 1979. Response to therapy in an experimental rabbit model of meningitis due to Listeria monocytogenes. J. Infect. Dis. 140: 287-294.

22. Bannatyne, R. M., and R. Cheung. 1979. Chloramphenicol bioassay. Antimicrob. Agents Chemother. 16: 4345.

23. Lietman, P. W., T. J. White, and W. V. Shaw. 1976 Chloramphenicol: an enzymological bioassay. Antimicrob. Agents Chemother. 10: 347-353.

24. Scheld, W. M. 1981. Pathophysiological correlates in bacterial meningitis. J. Infect. 3(Suppl. 1): 5-19.

25. Schaad, U. B., G. H. McCracken, Jr., C. A. Loock, and $M$. L. Thomas. 1981. Pharmacokinetics and bacteriologic efficacy of moxalactam, cefotaxime, cefoperazone, and rocephin in experimental bacterial meningitis. J. Infect. Dis. 143: 156-163.

26. Schaad, U. B., G. H. McCracken, Jr., C. A. Loock, and M. L. Thomas. 1980. Pharmacokinetics and bacteriologic efficacy of moxalactam (LY127935), netilmicin, and ampicillin in experimental gram-negative enteric bacillary meningitis. Antimicrob. Agents Chemother. 17: 406411.

27. Sande, M. A., R. J. Sherertz, O. Zak, and L. J. Strausbaugh. 1978. Cephalosporin antibiotics in the therapy of experimental Streptococcus pneumoniae and Haemophilus influenzae meningitis in rabbits. J. Infect. Dis. 137(Suppl.): S161-S168.

28. Beam, T. R. 1981. Vancomycin therapy of experimental pneumococcal meningitis caused by penicillin-sensitive and resistant strains. J. Antimicrob. Chemother. 7: 8999.

29. Sande, M. A., and K. B. Courtney. 1976. Nafcillin-gentamicin synergism in experimental staphylococcal endocarditis. J. Lab. Clin. Med. 88: 118-124.

30. Angrist, A., M. Oka, and K. Nakao. 1967. Vegetative endocarditis. Pathol. Annu. 2: 155-176.

31. Beam, T. R., and J. C. Allen. 1977. Blood, brain, and cerebrospinal fluid concentrations of several antibiotics in rabbits with intact and inflammed meninges. Antimicrob. Agents Chemother. 12: 710-716.

32. O'Donoghue, J. M., A. I. Schweilly, and H. N. Beaty. 1974. Experimental pneumococcal meningitis I. A rabbit model. Proc. Soc. Exp. Biol. Med. 146: 571-574.

33. Nolan, C. M., T. P. Monson, and W. C. Ulmer, Jr. 1979. Rosaramicin versus penicillin $G$ in experimental pneu- mococcal meningitis. Antimicrob. Agents Chemother. 16: 776-780.

34. Sande, M. A., O. M. Korzeniowski, G. M. Alliegro, R. O. Brennan, O. Zak, and W. M. Scheld. 1981. Intermittent or continuous therapy of experimental meningitis due to Streptococcus pneumoniae in rabbits. Preliminary observations on the post-antibiotic effect in vivo. Rev. Infect. Dis. 3: 98-109.

35. Chow, H. S., S. C. Sarpel, and R. B. Epstein. 1980. Pathophysiology of Candida albicans meningitis in normal, neutropenic, and granulocyte-transfused dogs. Blood. 55: 546-551.

36. Griffin, D. E. 1981. Immunoglobulins in the cerebrospinal fluid: changes during acute viral encephalitis in mice. J. Immunol. 126: 27-31.

37. Kinnman, J., H. Link, and A. Fryden. 1981. Characterization of antibody activity in oligoclonal immunoglobulin $\mathbf{G}$ synthesized within the central nervous system in a patient with tuberculous meningitis. J. Clin. Microbiol. 13: 30-35.

38. Haeney, M. R., R. A. Thompson, J. Faulkner, P. Mackintosh, and A. P. Ball. 1980. Recurrent bacterial meningitis in patients with genetic defects of terminal complement components. Clin. Exp. Immunol. 40: 16-24.

39. Veeder, M. H., J. D. Folds, W. J. Yount, and T. J. Lee. 1981. Recurrent bacterial meningitis associated with C8 and IgA deficiency. J. Infect. Dis. 144: 399-402.

40. Guckian, J. C., G. D. Christensen, and D. P. Fine. 1980 The role of opsonins in recovery from experimental pneumococcal pneumonia. J. Infect. Dis. 142: 175-190.

41. Hosea, S. W., E. J. Brown, and M. M. Frank. 1980. The critical role of complement in experimental pneumococcal sepsis. J. Infect. Dis. 142: 903-909.

42. Agbayani, M. M., J. Brown, C. T. Chang, J. Glass, and H. E. Evans. 1981. Effect of CSF on bacterial growth. Arch. Neurol. 38: 43-45.

43. Scheld, W. M., T. S. Park, R. G. Dacey, Jr., H. R. Winn, J. A. Jane, and M. A. Sande. 1979. Clearance of bacteria from cerebrospinal fluid to blood in experimental meningitis. Infect. Immun. 24: 102-105.

44. Scheld, W. M., R. G. Dacey, Jr., H. R. Winn, J. E. Welsh J. A. Jane, and M. A. Sande. 1980. Cerebrospinal fluid outflow resistance in experimental meningitis. Alterations with penicillin and methylprednisolone. J. Clin. Invest. 66: 243-253.

45. Doroshow, C., and M. A. Sande. 1981. Dynamics of bacterial killing in experimental pneumococcal meningitis by moxalactam. Intersci. Conf. Antimicrob. Agents Chemother. Proc. 21: Abstr. No. 456.

46. Scheld, W. M., J. P. Brodeur, M. A. Sande, and G. M. Alliegro. 1982. Comparison of cefoperazone with penicillin, ampicillin, gentamicin, and chloramphenicol in the therapy of experimental meningitis. Antimicrob. Agents Chemother. 22: 652-656.

47. Lepper, M. H., and H. F. Dowling. 1951. Treatment of pneumococcic meningitis with penicillin compared with penicillin plus aureomycin. Studies including observations on an apparent antagonism between penicillin and aureomycin. Arch. Intern. Med. 88: 489-494.

48. Cherubin, C. E., J. S. Marr, M. F. Sierra, and M. A. Becker. 1981. Listeria and gram-negative bacillary meningitis in New York City, 1972-1979: frequent causes of meningitis in adults. Am. J. Med. 71: 199-209.

49. Sande, M. A. 1981. Antibiotic therapy of bacterial meningitis: Lessons we've learned. Am. J. Med. 71: 507-510. 